\title{
Wykorzystanie tomografii ultradźwiękowej i MES do określenie nośności elementu betonowego
}

\author{
Ultrasonic tomography and FEM for evaluation \\ of load capacity of concrete element
}

\section{Streszczenie}

W artykule przedstawiono możliwość określenia nośności zamodelowanego elementu betonowego z imperfekcją materiałową w postaci strefy słabego betonu, o obniżonych parametrach materiałowych. Wykonano badanie tomografem ultradźwiękowym na elemencie betonowym w celu dokładnego zlokalizowania słabej strefy betonu. Na podstawie otrzymanych wyników wykonano symulację zniszczenia próbki w programie ABAQUS. Pozwoliło to na dokładne określenie stopnia osłabienia konstrukcji.

Słowa kluczowe: beton, tomografia ultradźwiękowa, MES

\begin{abstract}
The article presents possibility to determine the bearing capacity of the concrete element contains a zone of lower parameters of materials. Examination was done on the concrete element using ultrasonic tomography in order to locate accurately the weakened zone. On the basis of the results failure simulation at ABAQUS program was performed. This allowed to accurate determination of the degree of weakening of the structure.
\end{abstract}

Keywords: concrete, ultrasonic tomography, FEM

\section{Wstęp}

Metody nieniszczące są powszechnie używane w badaniach elementów betonowych, celem szybkiego diagnozowania różnego rodzaju imperfekcji materiałowych, np. stref słabego betonu. W ostatnich latach zauważono ich znaczący postęp, szczególnie w metodach akustycznych. Tomografia ultradźwiękowa jest jedną z takich metod. Jej główną zaletą jest możliwość badania obiektów dostępnych jednostronnie, dlatego z powodzeniem może być używana zarówno w warunkach laboratoryjnych, na budowie w trakcie realizacji inwestycji, oraz $\mathrm{w}$ przypadku badania istniejących konstrukcji [1], [2]. W artykule zaprezentowano badanie zamodelowanego elementu betonowego z imperfekcją materiałową w postaci słabej strefy betonu, przeprowadzone przy użyciu tomografu ultradźwiękowego. Na podstawie informacji uzyskanych podczas badania tomografem ultradźwiękowym przeprowadzono symulację zniszczenia elementu betonowego w programie MES, celem porównania nośności elementu ze słabą strefą betonu (imperfekcją materiałową) i bez słabej strefy betonu (bez imperfekcji).

\section{Krótki przegląd literaturowy}

W wielu pracach omówiono metodę tomografii ultradźwiękowej, jako przydatną w badaniach elementów betonowych takich jak płyty fundamentowe, konstrukcji o niere- gularnych kształtach, posadzki betonowe, słupy, powłoki, belki itp. [2,3]. Metoda ta służy do detekcji różnego rodzaju imperfekcji materiałowych, zapewnia wysoką dokładność w mierzeniu grubości obiektu przy jednostronnym dostępie, a ponadto pozwala na ocenę stanu zbrojenia w elementach żelbetowych [4]. Nadaje się także do badania słabych stref w elementach betonowych, które powstają na przykład w skutek niewłaściwego zagęszczania betonu w trakcie jego układania, czy też na skutek niewłaściwej jego pielęgnacji w trakcie dojrzewania $[1 \div 4]$.

\section{Tomografia ultradźwiękowa - metoda działania}

\section{Opis teoretyczny}

Tomografia ultradźwiękowa opiera się na propagacji fal sprężystych w badanym ośrodku. Źródłem wzbudzenia jest zwykle antena wielogłowicowa (składająca się z kilkudziesięciu zintegrowanych przetworników - głowic ultradźwiękowych), która jest stosowana zarówno do odbierania jak i przetwarzania sygnałów ultradźwiękowych.

Popularnym urządzeniem, wyposażonym w algorytm SAFT do sporządzania zobrazowań, jest tomograf ultradźwiękowy. Wykorzystuje on automatyczne wykonanie wielu równoległych linii skanowania, które pozwalają zbudować trójwymiarowy obraz, a następnie można go oglądać w dwuwymiarowych przekrojach. Urządzenie to stanowi antena

Dr hab. inż. Krzysztof Schabowicz, mgr inż. Łukasz Radzik - Politechnika Wrocławska, Wydział Budownictwa Lądowego i Wodnego. 
z zintegrowanym komputerem, która składa się z 48 przetworników (12 bloków, każdy po 4 przetworniki), wyświetlacz oraz przyciski kontrolujące działanie urządzenia. Każdy z przetworników wysyła fale poprzeczne o niskiej częstotliwości, charakteryzuje się dobrym kontaktem z badaną powierzchnią dzięki technologii DPC (dry point contact) oraz niezależnemu sprężynowemu zamocowaniu przetworników. W opisanych badaniach użyto tomograf ultradźwiękowy, który pokazano na rysunku 1.

a)

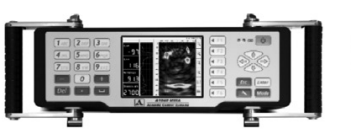

b)

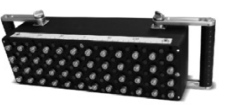

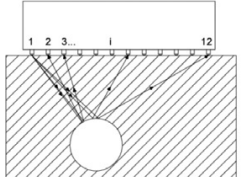

Rys. 1. a) Widok tomografu ultradźwiękowego od góry i od dołu b) schemat pracy tomografu

Fig. 1. a) View of ultrasonic tomograph, b) method of ultrasonic tomograph operation

Zgodnie z informacją producenta wspomniany tomograf może wysyłać fale poprzeczne o częstotliwościach od 50 do $200 \mathrm{kHz}$ [4]. W przedmiotowych badaniach wykorzystano fale poprzeczne o częstotliwości $55 \mathrm{kHz}$. Maksymalna głębokość zasięgu badania to $2500 \mathrm{~mm}$.

\section{Opis badanego elementu betonowego}

Przedmiotem badania był zamodelowany ze strefą słabego betonu element betonowy o wymiarach 1000 x 1000 x 500 $\mathrm{mm}$, wykonany z betonu C45/50 na kruszywie do $8 \mathrm{~mm}$. Badania miało na celu lokalizację słabej strefy betonu w elemencie betonowym. W wyniku wstępnych oględzin nie stwierdzono żadnych ubytków i rys na powierzchni badanego elementu betonowego. Naniesiono siatkę pomiarową na górnej i przedniej powierzchni elementu betonowego; o wymiarze 100 x 100 $\mathrm{mm}$. Element betonowy z naniesioną siatką i schemat z naniesioną siatką pomiarową przedstawiono na rysunku 2.

a)

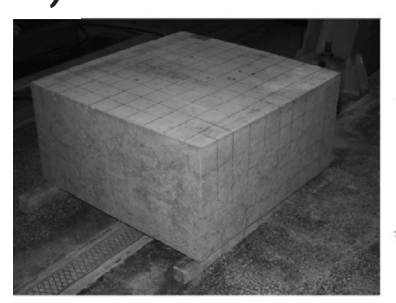

b)

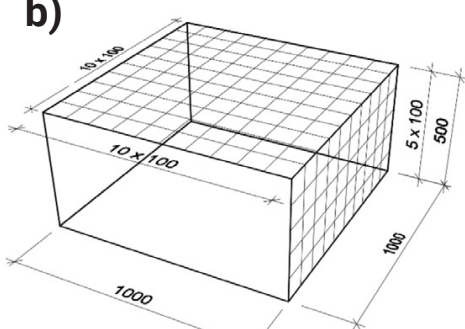

Rys. 2. Widok badanego elementu betonowego: a) z siatką pomiarową, b) schemat z naniesioną siatka pomiarową

Fig. 2. a) View of concrete specimen b) draft and dimensions

\section{Kolejność badań}

Badania elementu betonowego tomografem ultradźwiękowym rozpoczęto od przeskanowania jego górnej powierzchni. Kolejność badania przedstawiono na rysunku 3. Krok (przesunięcie) tomografu wynosił 100 mm w jednym i drugim kierunku badanego elementu. Następnie tomograf ultradźwiękowy obrócony został o $90^{\circ}$ stopni tak, aby ponownie zeskanować całą powierzchnię, celem uzyskania dla porównania dodatkowych rezultatów do analizy. Analogicznie została przebadana powierzchnia boczna elementu betonowego.

\section{Rezultaty badań}

W wyniku badań elementu otrzymano zobrazowania tomograficzne, które przedstawiono na rysunku 4. Na części z nich widoczne jest odbicie na głębokości około $500 \mathrm{~mm}$ (rysunek 4a), pozwalające na lokalizację dna elementu. Na pozostałych zobrazowaniach odbicie takie nie jest widoczne. Można zauważyć na nich jednak rozproszone odbicia w górnej i środkowej części zobrazowania tomograficznego, świadczące o występowaniu imperfekcji w obszarze skanowania. Z otrzymanych zobrazowań wynika, że nie jest to wtrącenie ciągłe. Są to zamodelowane strefy słabego betonu świadczące o nie zagęszczeniu betonu, którego skutkiem jest obniżenie wytrzymałości i modułu sprężystości betonu. Strefę słabego betonu, występowania takiej imprefekcji materiałowej, przedstawiono na rysunku $5 \mathrm{w}$ postaci zacienionego sześcianu. a)

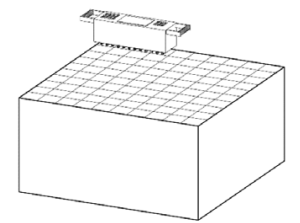

b)

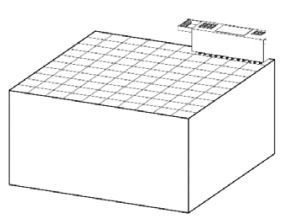

c)

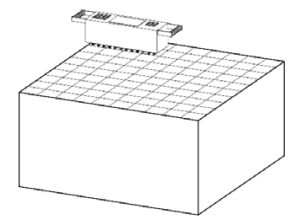

Rys. 3. Kolejność badania tomografem ultradźwiękowym: a) pozycja wyjściowa w lewym górnym rogu, b) ostatnia pozycja w rzędzie, c) pozycja wyjściowa $w$ drugim rzędzie

Fig. 3. The sequence of testing a) a starting position in the upper left corner b) the last position in a row, c) the starting position in the second rows

a)
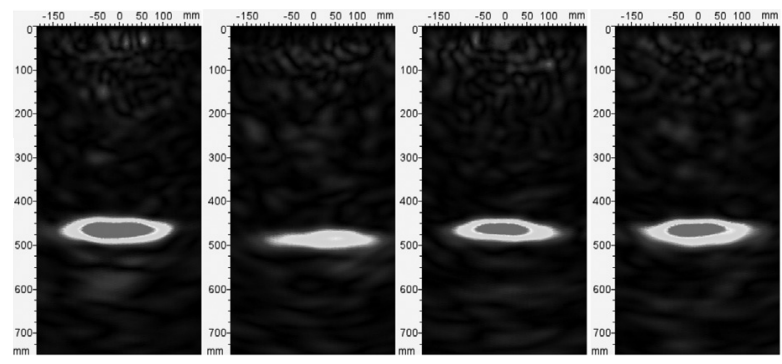

b)
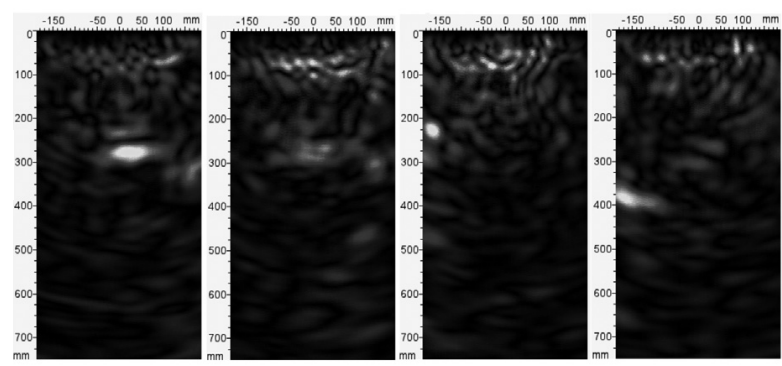

Rys. 4. Rezultaty badań - zobrazowania: a) pozwalające na lokalizację dna elementu, b) na których podstawie zlokalizowane zostały strefy osłabionego betonu

Fig. 4. Test results: a) scans with bottom localization, b) scans with weak material position

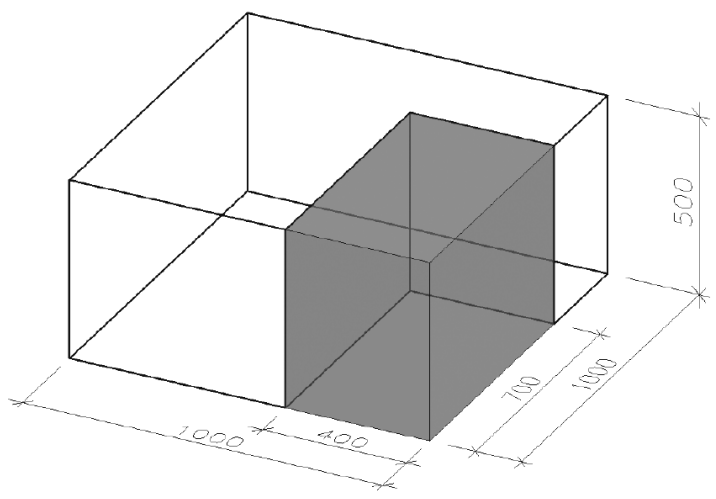

Rys. 5. Strefa słabego betonu wraz z jej orientacyjnymi wymiarami (zacieniony sześcian)

Fig. 5. Weakened area of the concrete with dimensions (shaded area) 


\section{Analiza MES}

W celu przeanalizowania jak duży wpływ na wytrzymałość całego elementu betonowego może mieć obecność strefy słabego betonu wykonana została analiza za pomocą programu wykorzystującego Metodą Elementów Skończonych. Obliczenia wykonane zostały w programie ABAQUS. Analiza polegała na zamodelowaniu 2 elementów betonowych o wymiarach $1000 \times 1000$ × 500 mm o wytrzymałości betonu C45/50. Materiał został odwzorowany poprzez nieliniowy model betonu "Concrete Damage Plasticity” (CDP) dokładnie przedstawiony w pracach $[5,6]$. Wybrane parametry materiału zostały zestawione $\mathrm{w}$ tabeli $\mathrm{nr} \mathrm{I}$. W jednym z modeli została wykonana strefa słabego betonu pokazana na rysunku 6a (obniżenie wytrzymałości o $40 \%$ wraz z obniżeniem modułu sprężystości o 14\%). W celu zapewnienia jednorodnego przekazania obciążenia zamodelowana została dodatkowo płytka stalowa (rys. 6a). Obciążenie zostało przyłożone do jej górnej powierzchni. Na dolnej powierzchni modelu zablokowano swobodę przemieszczeń. W obliczeniach użyto elementów C3D8 o wymiarach oczka siatki $25 \mathrm{~mm}$.

Tablica I. Parametry materiału CDP przyjęte w obliczeniach Table I. The material parameters of CDP model used in calculations

\begin{tabular}{|c|c|c|c|}
\hline \multirow{2}{*}{$\begin{array}{c}\text { Parametry } \\
\text { materiału }\end{array}$} & \multirow{2}{*}{$\mathrm{C} 45 / 50$} & \multicolumn{2}{|c|}{$\begin{array}{c}\text { Przyjęte parametry } \\
\text { dla modelu materiału } \\
\text { "Concrete Damage Plasticity” }\end{array}$} \\
\cline { 3 - 4 } & & $\beta$ & $38^{\circ}$ \\
\hline \multicolumn{2}{|c|}{ Sprężystość Betonu } & $\mathrm{m}$ & 1 \\
\hline $\mathrm{E}$ [Gpa] & 19,70 & $\mathrm{f}=\mathrm{f}_{\mathrm{bo}} / \mathrm{f}_{\mathrm{c}}$ & 1,12 \\
\hline $\mathrm{V}$ & 0,19 & $\mathrm{y}$ & 0,666 \\
\hline
\end{tabular}

Został wykonana analiza nieliniowa geometrycznie. W celu sprawdzenie nośności maksymalnej elementów betonowych analizę przeprowadzono do momentu braku przyrostu obciążenia, przy jednoczesnej znacznej deformacji świadczącej o „zniszczeniu modelu". a)

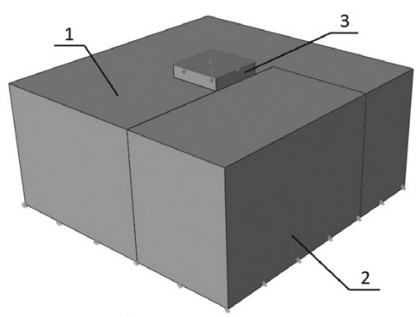

b)

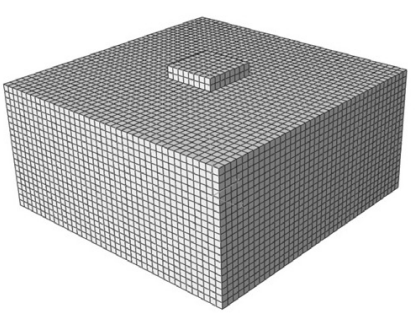

Rys. 6. a) Model elementu betonowego $z$ podziałem na strefy ( 1 - strefa "dobrego" betonu, 2 - strefa słabego betonu - obszar o obniżonej wytrzymałości betonu, 3 - stalowa płytka do przekazywania obciążenia), b) widok modelu z nałożoną siatką elementów skończonych (elementy C3D8)

Fig. 6. a) Model of the concrete element divided into parts (1 - an area without weak strength of concrete, 2 - the area of reduced strength of the concrete, 3 - steel plate to transfer load) b) view of the model overlaid with a grid of finite elements (elements C3D8)

Na rysunku nr 7 pokazano jak wygląda stan odkształcenia i naprężenia w przecięciu przez środek modeli w kroku obliczeniowym poprzedzającym ich zniszczenie (mapy te przedstawiają praktycznie stan odkształcenia i naprężenia w momencie zniszczenia elementu betonowego). Na rysunku 7a widoczne jest nierównomierne rozłożenie zarówno przemieszczenia jak i naprężenia w elemencie. Na rysunku $7 \mathrm{~b}$ widać, że rozkład ten jest niemal symetryczny.

Maksymalne siły, jakie zdołały przenieść oba modele zestawiono w tabeli I. Model bez strefy słabego betonu był w stanie „przenieść" 16\% więcej obciążenia.

Na rysunku nr 8 umieszczony został wykres ścieżki krytycznej dla obu modeli. Można z niego odczytać przemieszczenie górnej powierzchni modelu w zależności od przyłożonego obciążenia. Widzimy na nim o ile model strefy słabego betonu mniej się deformuje przy jednakowym stopniu obciążenia.

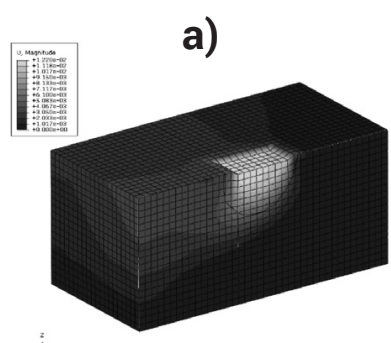

c)

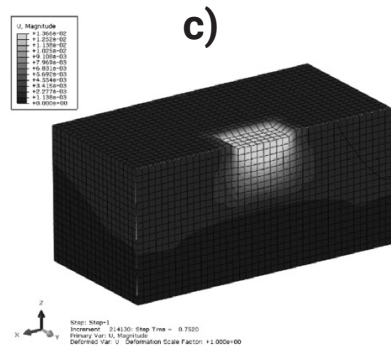

औ. b)

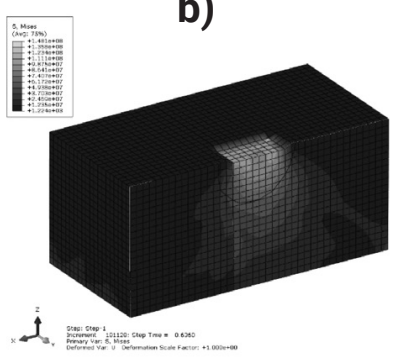

d)

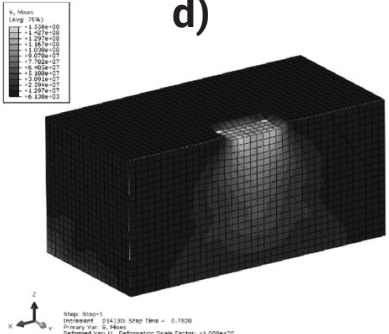

Rys. 7. Przecięcie przez modele elementu betonowego $w$ kroku obliczeniowym poprzedzającym ich zniszczenie: a) mapa deformacji (z lewej) oraz mapa naprężeń (z prawej) modelu z zamodelowaną strefą słabego betonu, b) mapa deformacji (z lewej) oraz mapa naprężeń (z prawej) modelu bez strefy słabego betonu

Fig. 7. Intersection by models sample in step calculation prior to their destruction a) deformation map (left) and a map of stresses (right) for sample with imperfection material, b) deformation map (left) and a map of stresses (right) for sample with no material imperfections

Tablica II. Zestawienie wyników obliczeń Table II. Summary of calculation results

\begin{tabular}{|c|c|c|}
\hline Model & $\begin{array}{c}\text { Materiału oraz jego } \\
\text { moduł sprężystości }\end{array}$ & $\begin{array}{c}\text { Nośność } \\
\text { elementu } \\
{[\mathrm{kN}]}\end{array}$ \\
\hline $\begin{array}{c}1 \text { (bez strefy słabe- } \\
\text { go betonu) }\end{array}$ & $\begin{array}{c}\text { Beton C45/50 } \\
\mathrm{E}=19,5 \mathrm{GPa}\end{array}$ & 3620 \\
\hline 2 (ze strefę słabego \\
betonu) & $\begin{array}{c}\text { Spadek wytrzyma- } \\
\text { łości w części } \\
\text { modelu o 40 \% } \\
\text { Spadek modułu } \\
\text { sprężystości o 14 \% }\end{array}$ & 3130 \\
\hline
\end{tabular}

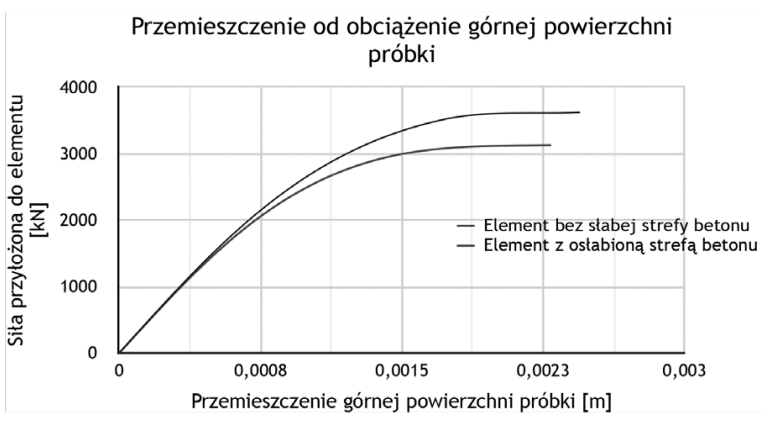

Rys. 8. Ścieżki krytyczne dla obu modeli

Fig. 8. Critical paths for both models 


\title{
Podsumowanie
}

Dzięki przeprowadzonym badaniom metodą tomografii ultradźwiękowej zlokalizowano słabą strefę w elemencie betonowym. Wystąpienie takiej strefy może być spowodowane niewystarczającym zagęszczeniem betonu lub jego nieodpowiednią pielęgnacją. Możliwe było w miarę dokładne wskazanie zasięgu słabej strefy, która w omawianym przypadku miała wymiary $400 \times 700 \mathrm{~mm}$.

Za pomocą specjalistycznego oprogramowania MES zamodelowano element betonowy wraz ze słabą strefą betonu. Pozwoliło to na oszacowanie nośności takiego elementu. Taka informacja może posłużyć m.in. do oceny jego dalszej przydatności do użytkowania.

\section{Literatura}

[1] J. Hoła, K. Schabowicz, „State-of-the-art non-destructive methods for diagnostic testing of building structures - anticipated development trends", Arch. Civ. Mech. Eng., t. 10, nr 3, ss. 5-18, 2010.

[2] V. K. Kachanov, I. V. Sokolov, D. V. Timofeev, M. V. Turkin, i E. V. Shalimova, "Detection of reflecting planes in ultrasonic tomography of concrete building structures", Russ. J. Nondestruct. Test., t. 46, nr 5, ss. 342-349, maj 2010.

[3] K. Schabowicz, „Ultrasonic tomography - The latest nondestructive technique for testing concrete members - Description, test methodology, application example", Arch. Civ. Mech. Eng., t. 14, nr 2, ss. 295

[4] A. O. De La Haza, A. A. Samokrutov, i P. A. Samokrutov, „Assessment of concrete structures using the Mira and Eyecon ultrasonic shear wave devices and the SAFT-C image reconstruction technique", Constr. Build. Mater., t. 38, ss. 1276-1291, Stycze 2013.

[5] S. V. Chaudhari i M. A. Chakrabarti, "Modeling of Concrete for Nonlinear Analysis using Finite Element Code ABAQUS", Int. J. Comput. Appl., t. 44, nr 7, ss. 14-18, kwi. 2012.

[6] T. Jankowiak i T. Łodygowski, „Identification of parameters of concrete damage plasticity constitutive model", Found. Civ. Environ. Eng., t. No. 6, ss. 53-69, 2005.

\section{MIEZDZYNARODOWA KONFERENCJA LUTOWNICZA}

\author{
Zarzad Glówny SIMP \\ Sestater \\ Dolnoślaska Sekcja Spawalnicza SIMP \\ Katedra Materlałoznawstwa, Wytrzymałości i Spawalnictwa Politechniki Wroclawskiej
}

Wydział Mechaniczny Politechniki Wrocławskiej

zapraszaja do udziału

w 5. Międzynarodowej Konferencji Naukowo - Technicznej pod hastem „POSTEP W TECHNOLOGIACH LUTOWANIA"

WROCLAW 26-28 wrzesnia 2016 (poniedziałek - środa)

pod przewodnictwem naukowym

Prof. dr hab. inż. dr h.c. (mult.) W/adystawa Wlosińskiego, PAN Warszawa

\section{KOMITET ORGANIZACYJNY}

Prof. dr hab. inż. Zbigniew/ Mirski - Przewodniczacy Komitetu Organizacyjnego

tel.71/3202142, e-mail: zbigniew.mirski@pwr.edu.pl

Dr inż. Tomasz Piwowarczyk - Sekretarz Komitetu Organizacyjnego

tel.692443319,e-mail: tomasz.piwowarczyk@pwr.edu.pl

Zainteresowanych Państwa prosimy o kontakt z sekretariatem Konferencj:

Mgrinz. Ewa Harapinska

tel. 784927814, e-mail: ewa.harapinska@pwr.edu.pl

www. konferencjalutownicza.pwr.wroc.pl 